\title{
A preliminary telemetry study of the migration of silver European eel (Anguilla anguilla L.) in the River Mosel, Germany
}

Behrmann-Godel J, Eckmann R. A preliminary telemetry study of the migration of silver European eel (Anguilla anguilla L.) in the River Mosel, Germany.

Ecology of Freshwater Fish 2003: 12: 000-000. (C) Blackwell

Munksgaard, 2003

Abstract - To study the behaviour of silver eels (Anguilla anguilla L.) during their downstream migration, particularly near a hydroelectric power dam, we tagged nine eels with ultrasonic transmitters and tracked their paths in the River Mosel, Germany. The onset of migration coincided with the first flood event that followed the full moon but was independent of daytime, because migration and turbine passage occurred during both day and night. During migration eels swam actively downstream with a velocity of $0.3-1.2 \mathrm{~m} \cdot \mathrm{s}^{-1}$. When migrating eels arrived at the dam, they either passed through the turbines immediately or stayed upstream of the powerhouse for up to 8 days, showing a characteristic circling behaviour. Circling eels repeatedly approached the trashrack, sprinted upstream, and finally passed through the turbines with the next high water discharge. These observations are discussed with regard to the design of appropriate downstream passage facilities.
J. Behrmann-Godel, R. Eckmann

Limnological Institute, University of Konstanz, 78457 Konstanz, Germany

Key words:

J. Behrmann-Godel, Limnological Institute, University of Konstanz, 78457 Konstanz, Germany; Tel.: + 497531882828; fax: +497531883533; e-mail: Jasminca.Behrmann@uni-konstanz.de

Accepted for publication June 6, 2002

Un resumen en español se incluye detrás del texto principal de este artículo.

\section{Introduction}

Declining elver catches at the European coasts and declining commercial eel catches in many European freshwater rivers provide strong evidence for a decrease of European eel (Anguilla anguilla L.) stocks in Europe (Moriarty 1992; Dekker 2000). In addition to other possible reasons for the decline of eel populations such as the reduction of silver eel fitness by the swimbladder nematode Anguillicola crassus (Sprengel \& Lüchtenberg 1991; Haenen et al. 1994; Kirk et al. 2000), obstacles to migration and increased hazards while crossing a rising number of dams during migration in freshwater might significantly reduce the number of spawners that return to the Sargasso Sea.
Hydroelectric dams aggravate both up- and downstream migration of fish. Although fishways can facilitate upstream migration, effective downstream migration facilities are still generally lacking (for reviews see Larinier \& Travade 1999; Odeh 1999). Silver eels are particularly affected by the lack of appropriate downstream migration facilities because they use the main current during their downstream passage and migrate near the riverbed (Tesch 1983, 1994; Jonsson 1991), a behaviour that automatically leads them to the water intake of hydroelectric power plants. With their elongate body shape, eels are particularly vulnerable to damage by turbine blades (Coutant \& Whitney 2000), which may ultimately result in high mortality rates. Numerous previous studies 
have shown that eel mortality rates owing to turbine impact range from 20 to $90 \%$ (Raben 1955; Berg 1986, 1987).

The Mosel, a tributary to the River Rhine, is regulated by 14 hydropower plants and is thus a typical representative of western European rivers. An evaluation at a hydroelectric power plant on the Mosel in 1993 revealed that 23\% eels caught at the turbine outlet showed severe injuries (Oberwahrenbrock et al. 1999). If the fraction of injured eels is assumed to be the same for all hydropower plants on the Mosel, then only $2.6 \%$ of silver eels that pass through 14 hydropower plants will reach the Rhine unharmed.

In order to design effective downstream passage facilities or to develop fish-friendly turbine management plans, it is crucial to have better knowledge of the time span of migration, the eels' swimming behaviour during migration and of their behavioural reactions when they arrive at a power dam. Thus, the aims of our study were to investigate: (i) whether the onset of eel downstream migration in the Mosel can be related to abiotic parameters as shown repeatedly in other freshwater rivers (Lowe 1952; Deelder 1954; Vøllestad et al. 1986; Jonsson 1991; for a review see Lucas \& Baras 2001); (ii) whether migration and turbine passage occur at a particular time of the day; and (iii) the behavioural reactions of migrating eels when they approach a hydropower plant.

\section{Study area}

The Mosel drainage basin expands over 28,156 $\mathrm{km}^{2}$ in France, Germany and Luxembourg. In the study area (Fig. 1), two major tributaries, the rivers Sauer and Saar, flow into the Mosel a few kilometre upstream of Trier dam. The study area is delimited by three dams on the rivers Mosel and Saar, while the upstream movement of eels in the Sauer is unrestricted by physical obstacles (Fig. 1). The rivers Mosel and Saar are almost completely canalised and open to navigation, while the Sauer is not navigable.

Fourteen hydropower plants are situated along the Mosel (Fig. 1). A typical hydropower station is equipped with four Kaplan turbines with a total capacity of $400 \mathrm{~m}^{3} \cdot \mathrm{s}^{-1}$. Mean discharge of the Mosel is about $330 \mathrm{~m}^{3} \cdot \mathrm{s}^{-1}$, but may fluctuate widely between a minimum of $14 \mathrm{~m}^{3} \cdot \mathrm{s}^{-1}$ in dry summers and a maximum of $4000 \mathrm{~m}^{3} \cdot \mathrm{s}^{-1}$ during winter floods. Consequently, all the river water runs through the turbines outside of winter flood water excess.

\section{Materials and methods}

In autumn 1999, silver eels of 70-100 cm length and $600-1700 \mathrm{~g}$ fresh weight were obtained from a professional fisherman, who caught eels with fyke nets. Fish were transported to a field laboratory where they were anaesthetised with 2-phenoxyethanol $\left(0.6 \mathrm{ml} \cdot \mathrm{1}^{-1}\right)$ and tagged immediately. Individually coded ultrasonic tags (Sonotronics, CHP-87-S/PRG94 HP, $65 \mathrm{~mm}$ long, $18 \mathrm{~mm}$ diameter, $8 \mathrm{~g}$ in air) were implanted into the body cavity following a method described by Baras \& Jeandrain (1998). Preliminary measurements at the River Mosel showed that at ultrasonic frequencies around $70 \mathrm{kHz}$ background noise was reasonably low even near the powerhouse, so that tags could be detected at 300-1000 m, depending on weather and hydraulic conditions. Five-centimetre-long incisions were closed with four stitches

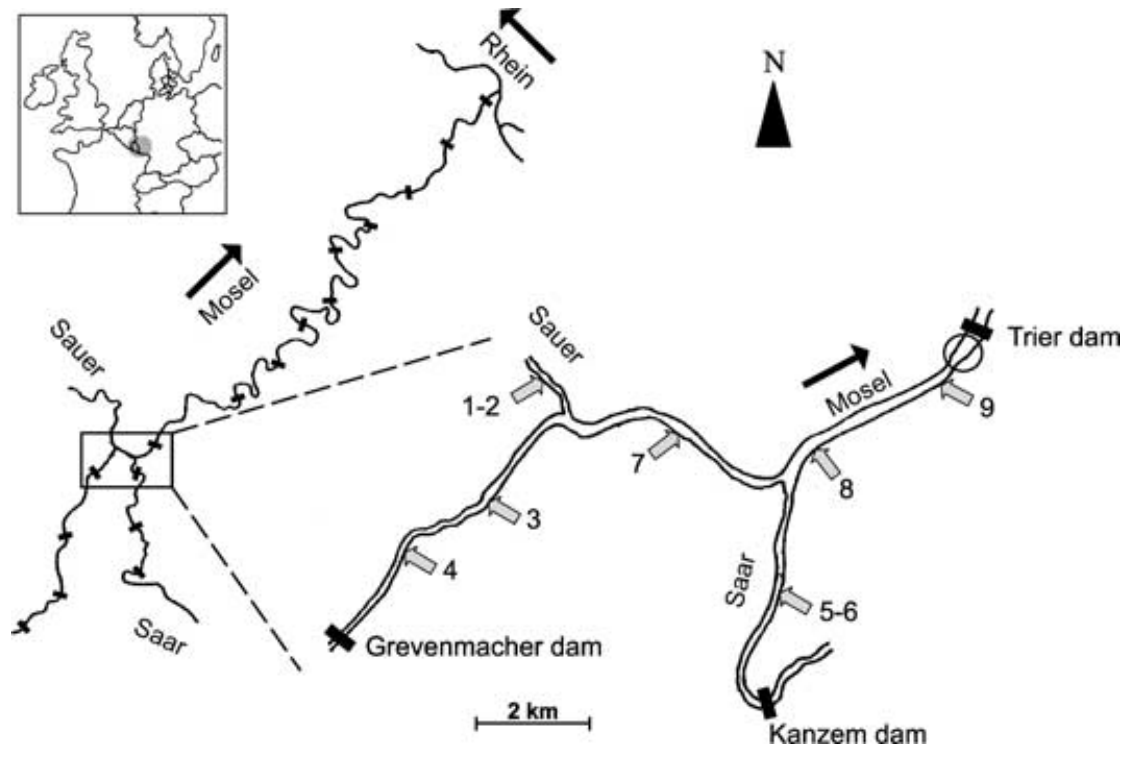

Fig. 1. Left: River Mosel with the tributaries Sauer and Saar. Black bars indicate hydroelectric power dams. Right: study area. Nine silver eels were caught upstream of Trier dam (circle) and released at different sites (grey arrows). Numbers refer to the eels as they are listed in Table 1. 
using resorbable suture (Ethicon, Vicryl Prolaktin 910). After recovery from anaesthesia for 10-20 min, nine eels were released at two different periods into the river stretch shown in Fig. 1. During the first observation period (8 September-3 October), three groups comprising two eels each were released into the rivers Mosel, Sauer and Saar, and during the second observation period (14 October-6 November) three eels were released into the Mosel (cf. Table 1 and Fig. 1). After release, we attempted to locate all eels twice daily, once during the day and once at night, using a narrow band receiver (Sonotronics, USR-96) and a directional hydrophone (Sonotronics, DH-2) on an open, outboard powered boat. If an eel was located while it was swimming, its movements were monitored permanently until the eel became stationary for at least $15 \mathrm{~min}$. When an eel approached the Trier dam powerhouse, it was located at least once every $2 \mathrm{~h}$ from sunset until mid-night. Whenever an eel could not be found in the previously located spot, a search was conducted over the entire study area (Fig. 1). When this search was unsuccessful, the tailrace of Trier dam was searched up to $5 \mathrm{~km}$ downstream. If we could not relocate the animal within the study period, we assumed that it had passed through the turbines and left the study area by downstream migration. When the beginning of migration could not be observed directly, the time of the start of migration was estimated as the time period between the last position fix and the start of our intensive search. To estimate the time of arrival at Trier dam, we added the time an eel would need to reach the dam. This time was calculated with an estimated swimming speed of $0.8 \mathrm{~m} \cdot \mathrm{s}^{-1}$ over ground, which was observed during migration of eel no. 1. The time when eels passed through the turbines was similarly estimated.
Positions were recorded as differentially corrected GPS coordinates (Garmin GPS II + equipped with DGPS decoder, GPS, GmbH, München) with a precision of approximately $1 \mathrm{~m}$. Near the Trier dam powerhouse, positions were estimated with an accuracy of approximately $\pm 20 \mathrm{~m}$ because we were not permitted to drive the boat closer than $100 \mathrm{~m}$ from the powerhouse. GPS coordinates were used to plot eel swim paths using a geographical information system (Arc View 3.1). Water discharge data were obtained from RWE/ Power AG. Modelling of water velocities was performed by Valitec Simulation Service in cooperation with the Institute for Hydraulic Engineering and Water Resources Management at Aachen University of Technology. Velocities are average values for the upper $80 \%$ of the water column but are not available for the near-bottom layer where velocity decreases exponentially (Carling 1992).

\section{Results}

\section{Tag implantation}

Tag implantation was successful in at least seven out of nine cases (one eel was lost after release and one eel either lost the tag or died 3 days after implantation). The fish could be tracked for several days or weeks, and eight eels migrated downstream during the study period (Table 1). Eel no. 6 was trapped in a fyke net about $120 \mathrm{~km}$ downstream 10 days after having disappeared from the study area. This eel had survived the turbine passage at five power plants, but was found dead in the fyke net and discarded by the fisherman, the cause of death could not be ascertained. As the fyke net was positioned with the opening facing downstream, the eel must have actively entered the trap. As the fisherman reported lesions on the

Table1. Observational data for nine ultrasonically tagged silver eel in the River Mosel system in 1999.

\begin{tabular}{|c|c|c|c|c|c|c|}
\hline Eel no. & $\begin{array}{c}\text { Date and } \\
\text { location of release }\end{array}$ & $\begin{array}{c}\text { No. of } \\
\text { position fixes }\end{array}$ & $\begin{array}{l}\text { Date of the } \\
\text { onset of } \\
\text { downstream } \\
\text { migration }\end{array}$ & $\begin{array}{c}\text { Days of circular } \\
\text { swimming behaviour }\end{array}$ & $\begin{array}{l}\text { Date of turbine } \\
\text { passage }\end{array}$ & $\begin{array}{l}\text { Distance between } \\
\text { last position fix } \\
\text { before migration start } \\
\text { and Trier dam }(\mathrm{km})\end{array}$ \\
\hline 1 & 8 September/Sauer & 5 & 3 October & 0 & 3 October & 11.4 \\
\hline $2^{1}$ & 8 September/Sauer & 1 & & & & \\
\hline 3 & 8 September/Mosel & 47 & 26 September & 6 & 10ctober & 15.0 \\
\hline $4^{2}$ & 8 September/Mosel & 43 & $>4$ October & - & $>4$ October & 9.3 \\
\hline $5^{2}$ & 8 September/Saar & 83 & 26 September & $>8$ & $>4$ 0ctober & 8.5 \\
\hline 6 & 8 September/Saar & 44 & 29 September & 1 & 30 September & 2.0 \\
\hline 7 & 18 October/Mosel & 12 & 26 October & 0 & 26 October & 13.0 \\
\hline $8^{3}$ & 18 October/Mosel & 49 & 21 October & & & 4.0 \\
\hline 9 & 18 0ctober/Mosel & 23 & 29 October & 0 & 29 October & 3.0 \\
\hline
\end{tabular}

${ }^{1}$ Eel was never found again after release.

${ }^{2}$ Turbine passage or migration and turbine passage occurred during the 10 days between observation periods (4-13 0ctober 1999).

${ }^{3}$ Eel probably died or lost its transmitter after downstream migration (see text). 
eel's body, it is assumed that this eel died in the fyke net as a consequence of multiple turbine passage rather than as a consequence of transmitter implantation.

\section{Downstream migration and turbine passage}

After release, eight out of nine eels stayed within the study area for several days up to more than 3 weeks (Table 1). The eels were either stationary for several days or they moved up- and down-

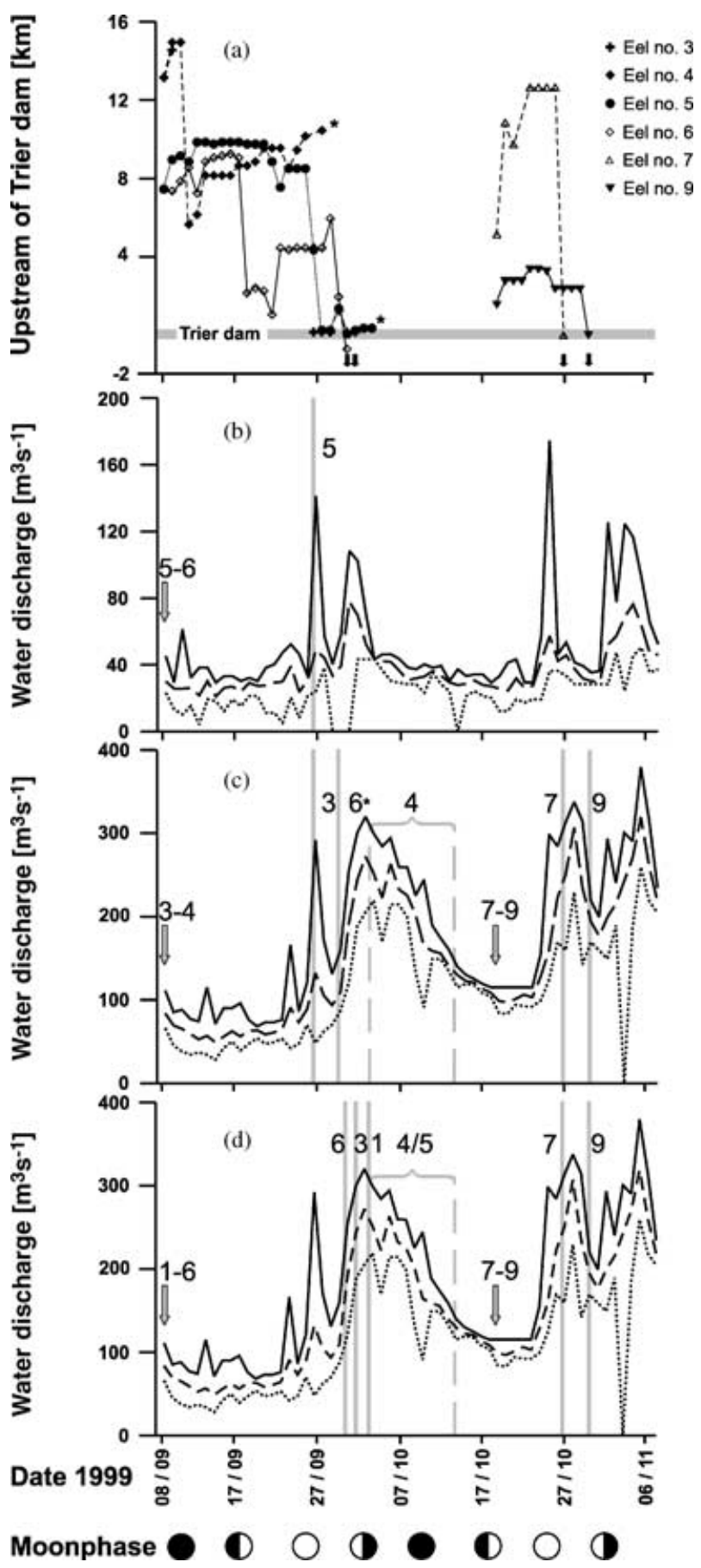

stream over several kilometres until they became stationary again (Fig. 2a).

Eels no. 1 and 2 which were released into the Sauer swam rapidly upstream immediately after release. Owing to the very shallow water level, we could not follow them by boat. Despite several attempts to locate these fish by operating the hydrophone from the riverbank, we were not able to locate them during their sojourn in the Sauer. Eel no. 2 was never found again. However, after 25 days, eel no. 1 was located in the Mosel, $2.2 \mathrm{~km}$ downstream from its release site in the Sauer. The fish was swimming downstream and could be located again $2 \mathrm{~h}$ later, $5.7 \mathrm{~km}$ further downstream. The difference between the observed downstream velocity of $0.8 \mathrm{~m} \cdot \mathrm{s}^{-1}$ and the modelled water velocity of $0.5 \mathrm{~m} \cdot \mathrm{s}^{-1}$ suggests that this animal was actively swimming at an average speed of $0.3 \mathrm{~m} \cdot \mathrm{s}^{-1}$. Eel no. 5 could also be tracked during its downstream migration, swimming at a speed of $1.2 \mathrm{~m} \cdot \mathrm{s}^{-1}$ relative to the river flow of $0.1 \mathrm{~m} \cdot \mathrm{s}^{-1}$. Once the eels changed their behaviour from stationary to downstream migration, they were oriented towards the centre of the river while during their stationary phase they remained close to the riverbanks.

The onset of downstream migration often coincided with a rapid increase of river discharge, especially the daily maximum discharge (Fig. 2b,c). These events generally occurred after the full moon. Similar results were obtained for the turbine passage, which also occurred exclusively under high waters (Fig. 2d). During the observation period, water temperature which was measured only occasionally, dropped from $21^{\circ} \mathrm{C}$ in September to $11^{\circ} \mathrm{C}$ in November. There was no relationship between time of day and onset of downstream migration or turbine passage. Eels no. 1 and 5 migrated downstream in full daylight while eel no. 6 migrated after sunset. Eels no. 1

Fig. 2. Migration and turbine passage of European silver eels in the Mosel drainage system, Germany. (a) Daily positions for eels no. 3-7, and 9 during their sojourn upstream of Trier dam. Arrows indicate turbine passage. Eel no. 6 was found on the day of turbine passage, $700 \mathrm{~m}$ downstream in the tailrace of Trier dam. Asterisks: eels no. 4 and 5 passed the turbines of Trier dam during the following days when no observations were performed (4 October-13 October 99). (b, c) Onset of downstream migration for eels no. 3-7 and 9 in the rivers Saar (b) and Mosel (c). Arrows indicate the time of release and grey bars the onset of migration. Brace: estimated time period of start of migration for eel no. 4. Numbers above arrows and beside bars designate individual eels. Maximum (solid line), mean (dashed line) and minimum (dotted line) daily water discharge as well as moon phase are plotted. Asterisk: eel no. 6 was originally released into the Saar but commenced downstream migration in the Mosel. (d) Turbine passage for eels no. 1, 3-7 and 9 at the Trier powerhouse. Legends, cf. Fig. 2b,c. 
Table 2. Daytime for the onset of silver eel downstream migration and for turbine passage at Trier dam in early September to late October 1999.

\begin{tabular}{|c|c|c|c|}
\hline \multirow[b]{2}{*}{ Eel no. } & \multicolumn{2}{|c|}{ Downstream migration } & \multirow{2}{*}{$\begin{array}{c}\text { Time of turbine } \\
\text { passage }\end{array}$} \\
\hline & Start & Arrival at Trier dam & \\
\hline 1 & Before 17:45 & $20: 50$ & $20: 50-21: 50$ \\
\hline 3 & - & - & $19: 45-20: 15$ \\
\hline 5 & $18: 50$ & $21: 30$ & - \\
\hline 6 & After 20:20 & $21: 30$ & $14: 00-16: 00$ \\
\hline
\end{tabular}

Local sunrise and sunset times were approximately 07:15 and 19:15 hours. Time (hh:mm) is European summertime.

and 3 went through the turbines after sunset while eel no. 6 did so in the afternoon (Table 2).

Three eels passed through the turbines on the day of arrival at the powerhouse, while three eels remained upstream of the powerhouse for 1, 6 and 8 days, showing a typical swimming pattern which we termed as circling behaviour. These fish approached the turbines, turned round in the forebay and swam rapidly upstream near the riverbank up to $1 \mathrm{~km}$ from where they approached the dam again (cf. Fig. 3). This behaviour was repeated several times per day and on consecutive days until finally the eels passed through the turbines (Table 1).

\section{Discussion}

Tag implantation apparently did not affect swimming behaviour of silver eels because they swam up- or downstream over considerable distances on the day(s) following tag implantation and release into the river (Fig. 2a). In only one case (eel no. 8) in which the eel moved to the ship lock of Trier dam after having migrated downstream 3 days after release, we were not sure whether the fish had died or lost the tag.

Overall, we could document downstream migration for eight out of nine ultrasonically tagged silver eels in the Mosel, we could estimate the onset of migration in seven cases and the time of turbine passage in five cases. We observed that a rapid increase of water discharge in autumn seems to trigger the beginning of downstream migration. Similar observations have been reported in earlier studies where eels were found to migrate during, or shortly after, flood events in autumn and mostly during nights with low light intensity (Lowe 1952; Deelder 1954; Vøllestad et al. 1986; 1994). From Fig. 2b,c, it appears that eels started to migrate on the first flood event that followed the full moon. However, since during our study water discharge always increased after the full moon, we could not rigorously evaluate the relative importance of moon phase and water discharge as a trigger for the onset of downstream migration. In contrast to other authors who observed that eel migration takes place primarily between sunset and mid-night (Bräutigam 1961; Vøllestad et al. 1986; Berg 1987), we found that silver eels migrate both during day and night (Table 2). Similarly, Tesch (1994), tracking migrating silver eels in the rivers Elbe and Weser, reported that eels migrated during day and night and that they migrated mid-stream with about the same velocity as the water current. Apparently, a rapid increase in water discharge may trigger the onset of downstream migration irrespective of the time of the day. We speculate that once migration has started,
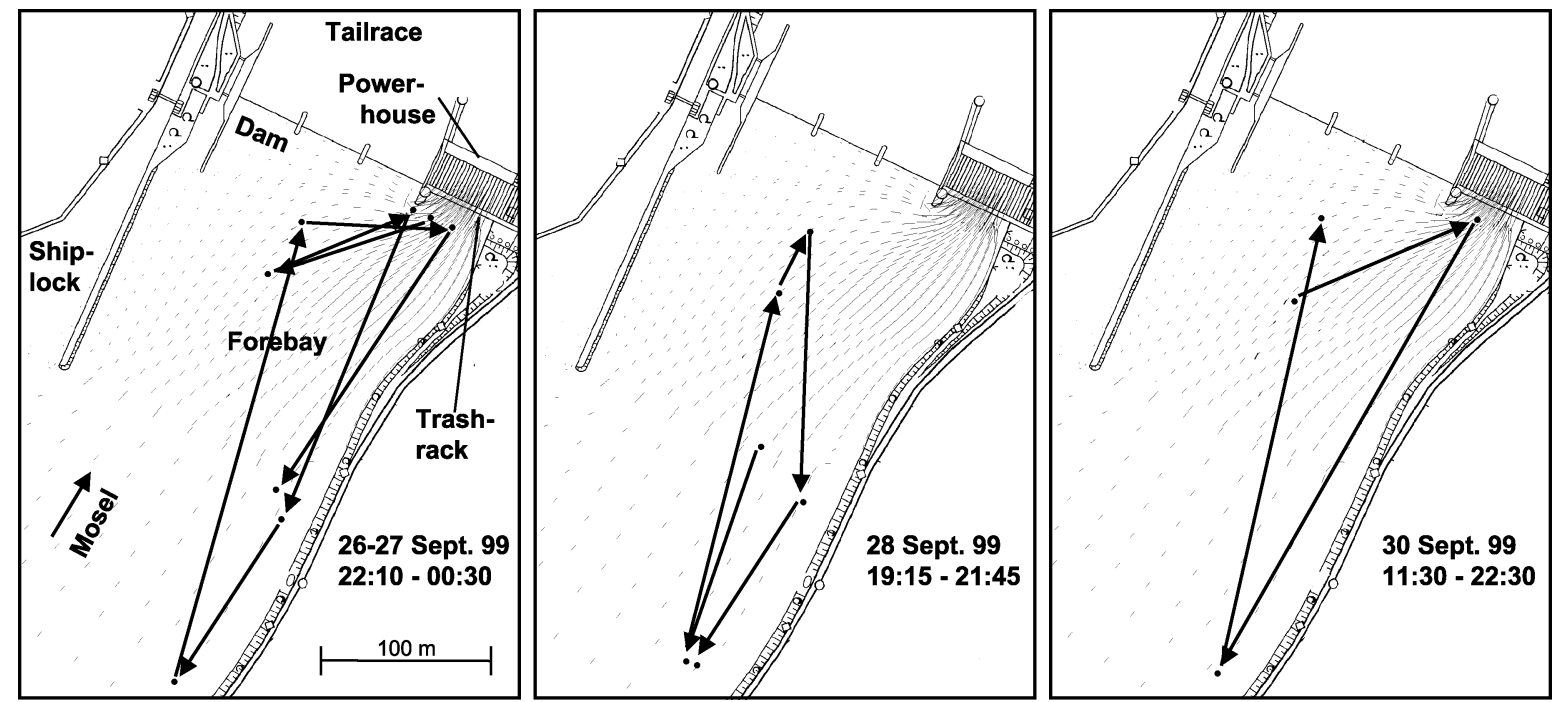

Fig. 3. Approximate swim paths for eel no. 5 showing the characteristic circling behaviour upstream of the Trier power house during three nights in September 1999. Dots represent precise position fixes (above the powerhouse) respective position estimates (near the water intake). Arrows connect positions in chronological order. Dashed lines indicate streamlines of local water flow; the length of each line corresponds to water velocity. The streamlines show that the entire discharge passed through the turbines. 
eels might then switch to a night-time migratory behaviour with stationary phases during daytime, which would explain the common observation of eels migrating mainly during night. Another possible reason why eels migrate during day is water turbidity. Every flood event that we observed in the Mosel led to a strong increase of turbidity. High turbidity, eventually coupled with overcast sky, could have resulted in markedly lower light intensities as compared with normal flow. Light intensity under these conditions though is definitely higher than during full-moon nights, which are known to almost completely inhibit silver eel migration (Lowe 1952).

To our knowledge, the characteristic circling behaviour of silver eels that we observed in the upstream region of the Trier powerhouse has not been previously described. Additional evidence for this circular swimming behaviour of eels is derived from years of experience of professional fishermen on the Mosel. Fishermen catch silver eels in fyke nets positioned as close to the turbine water intake as is allowed, with the opening facing downstream.

Water velocities at $20 \mathrm{~m}$ above the turbine intake were modelled for the time periods when eels either arrived at the powerhouse or passed through the turbines (Table 3). The typical circling behaviour was only observed at water velocities $<0.5 \mathrm{~m} \cdot \mathrm{s}^{-1}$ (discharge $<200 \mathrm{~m}^{3} \cdot \mathrm{s}^{-1}$ ) while turbine passage occurred only at the highest water velocities and discharges above $200 \mathrm{~m}^{3} \cdot \mathrm{s}^{-1}$. The actual velocities at the trashrack might have been even higher, but could not be modelled reliably.

Behavioural studies in flumes (Adam 1998) yielded results that support our field observations. When eels collided with a screen, they turned round and sprinted upstream. These flight reactions occurred only at water velocities of up to $1.0 \mathrm{~m} \cdot \mathrm{s}^{-1}$. At higher velocities, eels were no longer able to swim against the current but were pressed against the screen or even squeezed between the screen bars and then were carried further downstream.
The circling behaviour of eels can thus be interpreted as an avoidance reaction. Migrating silver eels may recognise the obstacle through noise or direct contact with the trashrack and then try to avoid these stimuli. If water velocities permit, they turn round and flee upstream. This behaviour is repeated until water velocity increases and eels are no longer able to swim against the current but are swept through the turbines of the power plant.

Our attempt to monitor the turbine passage of eel no. 1 after the animal had been observed during its downstream migration failed. The last position fix had been taken $3.8 \mathrm{~km}$ upstream of the Trier powerhouse approximately $2 \mathrm{~h}$ before we commenced monitoring the forebay. If we assume that the eel continued its downstream migration with the same velocity registered $\left(0.8 \mathrm{~m} \cdot \mathrm{s}^{-1}\right)$, it would have reached the Trier power plant and eventually passed through the turbines well before we had installed our equipment on the observation raft. Hence, it is not surprising that we failed to detect the precise instant of turbine passage of some eels, especially of those fish that did not display the circling behaviour upstream of the powerhouse. Based on these experiences, we would recommend the use of automated monitoring stations that should be installed as close to the turbine intake as possible, according to background noise and hydraulic conditions.

Although our observations are based on a very limited number of individuals, they suggest some useful ideas for the design of downstream passage facilities for eels. Most current efforts are concentrated on the design of trashracks, which prevent the eels from being squeezed between the bars and guide the fish to a bypass instead. Alternatively, a system to guide eels into a bypass system could be designed that focuses on those eels which circle in the forebay of a powerhouse. According to the fishermen's experience and our observations, this guidance system should be installed on the river bottom, as close to the powerhouse as possible, reaching from the riverbank towards mid-stream, and with the entrances look-

Table 3. River Mosel discharge and modelled water velocities when silver eels arrived at Trier dam and during turbine passage.

\begin{tabular}{|c|c|c|c|c|c|}
\hline \multirow[b]{2}{*}{ Eel no. } & \multicolumn{2}{|c|}{ Arrival at Trier dam } & \multicolumn{2}{|c|}{ Turbine passage } & \multirow[b]{2}{*}{ Circling behaviour } \\
\hline & $\begin{array}{l}\text { Discharge } \\
\left(\mathrm{m}^{3} \cdot \mathrm{s}^{-1}\right)\end{array}$ & $\begin{array}{l}\text { Water velocity } \\
\left(\mathrm{m} \cdot \mathrm{s}^{-1}\right)\end{array}$ & $\begin{array}{l}\text { Discharge } \\
\left(\mathrm{m}^{3} \cdot \mathrm{s}^{-1}\right)\end{array}$ & $\begin{array}{l}\text { Water velocity } \\
\left(\mathrm{m} \cdot \mathrm{s}^{-1}\right)\end{array}$ & \\
\hline 1 & 290 & 0.97 & 290 & 0.97 & No \\
\hline 3 & 140 & 0.46 & 300 & 1.00 & Yes \\
\hline 5 & 107 & 0.36 & - & - & Yes \\
\hline 6 & 130 & 0.43 & 200-250 & $0.7-0.8$ & Yes \\
\hline 7 & 240 & 0.79 & 240 & 0.79 & No \\
\hline 9 & 200 & 0.66 & 200 & 0.66 & No \\
\hline
\end{tabular}


ing downstream. As with other guidance systems, our proposed system will not sample all migrating silver eels, but it may be installed in addition to modified trashracks. Such a system should definitely be considered in all cases where the modification of trashracks is not possible or economically prohibitive.

\section{Resumen}

1. Para estudiar el comportamiento de anguilas (Anguilla anguilla L.) plateadas durante la migración aguas abajo, especialmente a su llegada a un embalse de energía, marcamos 9 individuos con trasmisores ultrasónicos y seguimos sus movimientos en el rio Mosel (Alemania).

2. Las anguilas fueron capturadas, marcadas e inmediatamente soltadas en Septiembre y en Octubre del año 1999, en varias localidades de la cuenca del Mosel. El comienzo de la migración coincidió con las primeras riadas despues de la luna llena pero fueron independientes de la hora del dia ya que tanto la migración como el paso por la turbina ocurrieron tanto de dia como de noche.

3. Durante la migración, las anguilas nadaron activamente aguas abajo a velocidades de $0.3-1.2 \mathrm{~m} \cdot \mathrm{s}^{-1}$. Cuando las anguilas migradoras alcanzaron el embalse, o bien pasaron la turbina inmediatamente o permanecieron aguas arriba hasta 8 dias, mostrando un comportamiento cíclico característico. Las anguilas circularon repetidamente al aproximarse, esprintaron hacia arriba y finalmente cruzaron la turbina al llegar la siguiente riada. El paso por la turbina solamente se produjo cuando el caudal, $20 \mathrm{~m}$ por encima de la entrada de la turbina, alcanzó los $200 \mathrm{~m}^{3} \cdot \mathrm{s}^{-1}$ (velocidad del agua bien por debajo de $1.0 \mathrm{~m} \cdot \mathrm{s}^{-1}$ ). Cuando el caudal estuvo por debajo de $200 \mathrm{~m}^{3}$, las anguilas circularon alrededor de la entrada. Estas observaciones coinciden con otros estudios sobre la migración de anguilas plateadas y se discuten en el contexto del diseño de estructuras de paso para peces en migraciones aguas abajo.

\section{Acknowledgements}

We wish to thank Elmar Müllen, Manfred Gerdts and Lothar Kroll for assistance during fieldwork and Reinhard Kowalski and Dirk Schwanenberg who provided modelled water velocities. We are particularly grateful to E. Baras and one unknown referee for their helpful comments on the manuscript. This study was undertaken and financed within the framework of the Aalschutzinitiative Rheinland-Pfalz RWE Power AG.

\section{References}

Adam, B. 1998. Aalabwanderung - Ergebnisse von Versuchen in Modellgerinnen. In: Lukowski, V.M., ed. Durchgängigkeit Von Fließgewässern für Stromabwärts Wandernde Fische. Hamburg: Deutscher Fischerei-Verband E. V, pp. 37-68.

Baras, E. \& Jeandrain, D. 1998. Evaluation of surgery procedures for tagging eels Anguilla anguilla (L.) with biotelemetry transmitters. Hydrobiologia 371/372: 107-111.

Berg, R. 1986. Fish passage through Kaplan turbines at a power plant on the River Neckar and subsequent eel injuries. Vie Milieu 36: 307-310.
Berg, R. 1987. Fischereischäden durch Turbinen. Arbeiten des Deutschen Fischerei-Verbandes 44: 41-47.

Bräutigam, R. 1961. Über Versuche zur Intensivierung des Blankaalfanges durch die Kombination von Lichtsperren und Großreusen und ihre grundsätzlichen Bedingungen. Fischerei-Foschung 1/2: 19-25.

Carling, P.A. 1992. In-stream hydraulics and sediment transport. In: Calow, P. \& Petts, G.E. eds. The rivers handbook. Part 1. Hydrological and ecological principles. Oxford: Blackwell Scientific Publications, pp. 101-125.

Coutant, C.C. \& Whitney, R.R. 2000. Fish behavior in relation to passage through hydropower turbines: a review. Transactions of the American Fisheries Society 129: 351-380.

Deelder, C.L. 1954. Factors affecting the migration of the silver eel in Dutch inland waters. Journal du Conseil Internationale Pour l'Exploration de la Mer 20: 177-185.

Dekker, W. 2000. The fractal geometry of the European eel stock. ICES Journal of Marine Science 57: 109-121.

Haenen, O.L.M., Van Banning, P. \& Dekker, W. 1994. Infection of eel Anguilla anguilla (L.) and smelt Osmerus eperlanus (L.) with Anguillicola crassus (Nematoda: Dracunculoidea) in the Netherlands from 1986 to 1992. Aquaculture 126: 219-229.

Jonsson, N. 1991. Influence of water flow, water temperature and light on fish migration in rivers. Nordic Journal of Freshwater Research 66: 20-35.

Kirk, R.S., Lewis, J.W. \& Kennedy, C.R. 2000. Survival and transmission of Anguillicola crassus Kuwahara, Niimi \& Itagaki, 1974 (Nematoda) in seawater eels. Parasitology 120: 289-295.

Larinier, M. \& Travade, F. 1999. Downstream migration. Problems and facilities. Bulletin Francais de la Peche et de la Pisciculture 353/354: 181-210.

Lowe, R.H. 1952. The influence of light and other factors on the seaward migration of the silver eel (Anguilla anguilla L.). Journal of Animal Ecology 21: 275-309.

Lucas, M.C. \& Baras, E. 2001. Migration of Freshwater Fishes. Blackwell Science, Oxford.

Moriarty, C. 1992. Catches of Anguilla anguilla elver on the Atlantic Coast of Europe 1989-1990. Irish Fisheries Investigations Series A (Freshwater) 36: 33-34.

Oberwahrenbrock, G.K., Kroll, L., Sistenich, H.P., Eckmann, R., Reiber, J., Rettemeier, K., Köngeter, J. \& Jörgensen, L. 1999. Projektfortschrittsbericht 1. Aalschutzinitiative Rheinland-Pfalz/RWE Energie AG. Trier. $77 \mathrm{pp}$.

Odeh, M. 1999. Innovations in fish passage technology. Bethesda, Maryland: American Fisheries Society.

Raben, K.V. 1955. Kaplanturbinen und Fische. Die Wasserwirtschaft 47: 97-100.

Sprengel, G. \& Lüchtenberg, H. 1991. Infection by endoparasites reduces maximum swimming speed of European smelt Osmerus eperlanus and European eel Anguilla anguilla. Diseases of Aquatic Organisms 11: 31-35.

Tesch, F.W. 1983. Der Aal. Hamburg und Berlin: Paul Parey. 340 pp.

Tesch, F.W. 1994. Tracking of silver eels in the Rivers Weser and Elbe. Fischökologie 7: 47-59.

Vøllestad, L.A., Jonsson, B., Hvidsten, N.A. \& Naesje, T.F. 1994. Experimental test of environmental factors influencing the seaward migration of European silver eels. Journal of Fish Biology 45: 641-651.

Vøllestad, L.A., Jonsson, B., Hvidsten, N.A., Naesje, T.F., Haraldstad, Ø. \& Ruud-Hansen, J. 1986. Environmental factors regulating the seaward migration of European silver eels (Anguilla anguilla). Canadian Journal of Fisheries and Aquatic Sciences 43: 1909-1916. 